\title{
ВІЙНА ЗА УКРАЇНУ: ВІД ІНФОРМАЦІЙНИХ ОПЕРАЦІЙ ДО ПРЯМОГО ВТОРГНЕННЯ
}

\author{
Ангеліка Ділай \\ Військовий інститут \\ Киїського національного університету імені Тараса Шевченка, \\ вул. Ломоносова, 81, 03189, Київ, Украӥна, \\ e-mail: lika dilay@ukr.net \\ https://orcid.org/0000-0002-8255-4941
}

У цій статті проаналізовано інформаційні операції як підготовчий етап захоплення кордонів держав, вивчено стратегічні документи, котрі регулюють діяльність підрозділів інформаційної боротьби. Автори звернули увагу на поняття впливу як основи здійснення інформаційних операцій. Також автори здійснили спробу виокремити проблемні питання протидії України інформаційним операціям з боку Кремля.

Ключові слова: інформаційні операції, вплив, ЗМК.

Постановка проблеми. Майбутнє не буде продовженням сьогоднішніх трендів. Інформаційне протистояння виходить на абсолютно новий рівень, воно торкається всіх сфер людського життя і фактично стало бойовими діями. Інформаційними операціями нині стало практично все: дії, вислови, меседжі, сторітеллінг, символи тощо.

В епоху інформаційного суспільства історія розвитку будь-якої незалежної держави $є$ тісно переплетеною з інформаційними операціями: від дезінформації та маніпуляцій до спланованих інформаційних атак на об'єкти державного значення, i, не менш важливо, боротьба сьогодні направлена за свідомість суспільства. Наша держава зіштовхнулася із проблемою інформаційної експансії, де поведінка населення регулюється через емоційний стан, навіяний засобами масової комунікації, тому не вирішеним зостається питання захисту інформаційного простору України, як 3 кібернетичної точки зору, так і захист контенту, який більшою мірою спрямований на людей.

Аналіз останніх досліджень 3 проблематики роботи. Питання інформаційного протистояння, технологіями інформаційного впливу та відповідно інформаційної безпеки у різні часи досліджували такі вчені, як В. Горбулін, Г. Почепцов, В. Крисько, А. Петренко, В. Толубко, Т. Дзюба, П. Померанцев та інші. Однак варто зауважити, що найбільш впливовими вважаються роботи науковців збройних сил США, які сьогодні намагаються адаптувати під власні потреби практично всі армії країн-членів НАТО та їхніх партнерів.

(с) Ділай А., 2019

Наукове рецензування і рекомендація до друку - доц. О. П. Позняков. 
Метою цієї статті є розгляд проблеми інформаційного протистояння України в умовах глобалізації, а також через призму проведення Операції об'єднаних сил як нового виклику інформаційній безпеці світу.

Для досягнення поставленої мети потрібно вирішити такі завдання: проаналізувати розвиток та трансформацію поняття «інформаційні операції», виокремити основний компонент їхнього функціонування, вивчити досвід проведення інформаційних РФ проти України, дослідити взаємозв'язок інформаційних операцій та фізичного театру воєнних дій.

Під час активного розвитку конфлікту та після його завершення важливу роль відіграють мас-медіа, які формують думку аудиторії про саме явище та його наслідки. Розвитку конфлікту багато в чому сприяють саме засоби масової комунікації, які, маніпулюючи думками аудиторії та пропагуючи певні ідеали, зумовлюють виникнення реакції своєї аудиторії, яка в подальшому й впливає на перебіг конфліктної ситуації.

По суті, сучасна боротьба держави за власну незалежність - це свого роду й інформаційна боротьба, яка здійснюється в таких формах:

- інформаційної розвідки - пошуку, збору, обробки та аналізу інформації про інформаційні ризики і загрози;

- планування інформаційних заходів тактичного (локального, внутрішньоукраїнського), оперативного (що зачіпає країни-сусіди держави) і стратегічного (спільно з державами, які впливають на розвиток геополітики) рівнів;

- проведення заходів інформаційного характеру (інформаційних операцій, дій, акцій) в цілях реалізації завдань внутрішньої і зовнішньої політики держави;

- оцінки ефективності інформаційних заходів - визначення рівня досягнення успіху [1].

Однак у матеріалах ЗМК ми найчастіше зустрічаємо дещо публіцистичне окреслення сьогоднішнього конфлікту: проти нашої держави ведеться інформаційна війна. Дехто під цим терміном розуміє абсолютно всі дії в інформаційному просторі, інші ж використовують наступні терміни як «інформаційна боротьба», «інформаційне протистояння», «інформаційні операції» тощо. Проте, всі ці дефініції містять у собі схожість - це вплив на свідомість конкретної особи або суспільства в цілому.

Вважаємо за доцільне, розглянути саме поняття впливу, оскільки він стає як способом досягнення самої цілі, так і результатом певною діяльності. Особливо, коли питання стосується інформаційних операцій, де стержневою ланкою вивчення стає інформаційно-психологічний вплив. Зокрема це стосується досвіду дій збройних сил і спецслужб США та їх союзників під час операцій у Перській затоці, Сомалі, Гаїті, Боснії, Косові, Югославії, Афганістані тощо [2, с.258].

Щоб зрозуміти сутність інформаційно-психологічного впливу, який ліг в основу ведення інформаційних операцій, варто розглянути окремо інформаційний вплив та психологічний. Так, більшість дослідників під інформаційним впливом розуміють будь-який вплив на людину чи групу людей через інформацію.

Цікавим є підхід розуміння інформаційного впливу у медіапсихології, де комунікація опосередкована технічними засобами (ЗМК) і не обмежується окремими учасниками взаємодії «тут і тепер». Відповідно інформаційний вплив має інші характеристики: дистанційованість, масовість, опосередкованість (Див. табл.1) [3, с. 35]. 


\section{Групи визначень інформаційного впливу залежно від підходу (дисципліни)}

\begin{tabular}{c|l|l|l}
\hline Групи & \multicolumn{1}{|c}{ Дисципліна } & \multicolumn{1}{|c|}{ Тип комунікації } & \multicolumn{1}{|c}{ Інформаційний вплив } \\
\hline А & $\begin{array}{l}\text { Соціальна психологія } \\
\text { комунікації }\end{array}$ & $\begin{array}{l}\text { Міжособистісна } \\
\text { комунікація }\end{array}$ & $\begin{array}{l}\text { Процес соціального порів- } \\
\text { няння, мотивом якого єа- } \\
\text { жання індивіда бути корект- } \\
\text { ним у свої судженнях }\end{array}$ \\
\hline Б & Медіапсихологія & Масова комунікація & $\begin{array}{l}\text { Опосередкований вплив на } \\
\text { аудиторію через різних посе- } \\
\text { редників (мас-медіа) }\end{array}$ \\
\hline В & $\begin{array}{l}\text { Психологі мови: } \\
\text { експериментальна } \\
\text { риторика, прагматика }\end{array}$ & Текст повідомлення & $\begin{array}{l}\text { Мовний вплив у широкому } \\
\text { розумінні (вербальний образ- } \\
\text { ний) }\end{array}$ \\
\hline
\end{tabular}

Психологічний вплив найчастіше ототожнюється із впливом у широкому розумінні. Головною метою впливу є зміна поведінки і діяльності об’єкта, на який спрямована інформація чи дія.

Психологічний вплив - це вплив на людей (на окремих індивідів і на групи), який здійснюється з метою зміни ідеологічних і психологічних структур їх свідомості та підсвідомості, трансформації емоційних станів, стимулювання певних типів поведінки з використанням різних способів прихованого психологічного примусу [4].

Оскільки інформаційно-психологічний вплив акумулює в собі два поняття, вважаю за доцільне взяти за основу останне визначення, однак посилити його. $\mathrm{Ta}$ ким чином, інформаційно-психологічний вплив - це організована дія на свідомість та підсвідомість особистості чи суспільства за допомогою слова чи інформації та використанням інформаційний засобів чи технологій для зміни установок, емоцій та поведінки. 3 цього визначення можна зробити висновок, що інформаційно-психологічний вплив є поєднанням різних видів впливу та є більш ефективним.

Як зазначав Пітер Померанцев: «Нині існує низка теорій інформаційної війни. Російська теорія апелює до інформаційної та психологічної війни, сутність якої полягає в тому, щоб підкорити іншу країну, навіть не торкаючись їі. Ядром інформаційної війни є людська свідомість, психологічна сфера. В інформаційній боротьбі йдеться не лише про пропаганду, медіадебати, переконання. Це військова доктрина, що включає кіберагресію, економічні, медійні засоби та інші засоби» [5].

Теоретичне осмислення проблематики інформаційних воєн почалося в 90-ті роки XX ст. Першою структурою, яка цим займалася, був американський Авіаційний університет. Спонукали до нових підходів розробки, які велися в системі ВПС, на тему, якою може бути війна 2025 (і наступних років). Тобто, людям довелося відірватися у своєму мисленні від того, яким буде «залізо», а почати думати про принципово нові сфери.

Як часто наголошує дослідник Г. Почепцов, термін «інформаційні війни» суто публіцистичний чи політичний. Військова сфера використовує інший термін - «інформаційні операції», $\epsilon$ ще «психологічні операції». Словосполучення «інформацій- 
ні війни» не вживають тому, що війни можна вести тоді, коли дійсно йде війна, тоді як операиіями можна займатися завжди. Деякі країни додатково вводять власні визначення, наприклад, Австралія замість «інформаційних операцій» вживає термін «інформаційні дії» [6].

Аналізуючи сучасні тренди ведення агресивних дій в інформаційному простоpi, Г. Почепцов зазначає, що інформаційні операції по своїй суті еволюціонують до операцій впливу. Саме таке визначення можна найчастіше зустріти у документах HATO.

Модель операцій впливу грунтується на моделі соціальної комунікації і визначаються як комплекс дій, які спрямовані на зміну усвідомлення, поведінки, намірів та процесів прийняття рішень лідерів, груп або цілих народів шляхом надання відповідної інформації на когнітивному рівні [7].

Відповідно до вищезазначеного, основними складовими операцій впливу, як і в соціальній комунікації є суб'єкт впливу - повідомлення - цільова аудиторія.

Аналіз інформаційного простору свідчить про те, що операції впливу містять чотири основних компоненти: цивільно-військове співробітництво; інформаційні операції; операції з безпеки та операції в засобах масової інформації (медіа-операції) [8].

Саме вивчення медіа-операцій дало поштовх до розуміння того, що термін «інформаційна війна» не відображає в повній мірі сучасних тенденцій. Адже для інформаційної війни, так і для інформаційних операцій, головним стало повідомлення, тобто зміст. Проте сьогодні сфера соціальних комунікацій настільки динамічна, що орієнтуватися лише на статичний зміст неможливо. На перший план виходять смисли та образи, які вдало використовуються терористами, праворадикальними групами, політиками тощо.

Вивчаючи прийоми інформаційних впливів Росії на територію України, варто відмітити, що Кремль перейшов від агресивної комунікації до використання комунікації на основі страху, паніки, придушення оптимізму. Замість категоричної тези «України ніколи не існувало» Кремль став просувати меседжі «Слава Україні, Порошенко - зрадник» та «Україна існує, але вона нікому не потрібна - Свропа і Америка кинули Україну». Замість малювання радикальних образів «хунти» Кремль почав застосовувати риторику, що «українців мільйонами вбивають на Донбасі - треба зупинити війну» [9].

Все це носить тривалий у часі характер. Адже подібна інформація спрямована на зміну знання, що заторкує смислову сферу. Це в свою чергу впливає на формування картини світосприйняття, таким чином і ефективність впливу збільшується.

Як гнаголошує Г. Почепцов, пострадянський простір сьогодні, і Україна зокрема, йдуть між двома стратегіями. Технічно орієнтовані кіберспеціалісти намагаються побудувати «стіну». Але це може допомогти виключно у випадку інформаційної війни. Вона може вибудовувати захист саме завдяки фільтрації повідомлень.

Що стосується смислової війни, то неможливо зупинити масову культуру. Вона об'єднує в собі характеристики інформаційного, віртуального і комерційного продукту, в той час як у системі інформаційної війни діє об’єднання інформаційного і військового чи інформаційного й політичного продукту [10].

Так само, як не можна безапеляційно стверджувати, що на нас діє пропаганда. Адже поширення технологій відкрило можливості споживати інформацію вибірково, перевіряти ії та піддавати сумніву. А пропагандистські методи більш ефективні 
Ділай $A$.

у закритих системах, поширюються через монополізовані ЗМІ чи обмежуються законом. Саме так діють у Росії, де певна картина світу нав’язується суспільству через постійне масове тиражування інформації одними й тими ж каналами.

В Російській Федерації у структурі Міністерства оборони України вже давно створено підрозділ інформаційних операцій [11]. Точно підтверджено, що такі війська займаються відбиттям хакерських атак, контрпропагандою як всередині країни, так і за їі межами, в інтернеті, у ЗМІ тощо. Російські політики вже давно визнали, що сьогодні боротьба переходить із фізичного виміру у вимір цифровий.

Зокрема, як пише Тетяна Попова, в «Доктрине информационной безопасности Российской Федерации», яка була затверджена президентом Росії 9 вересня 2000 року зазначалося, що джерелом зовнішньої загрози інформаційній безпеці Російської Федерації є розробка певними державами концепцій інформаційних війн. Однак, для нас цікавим стане подібний документ, але датований кінцем 2016 року. Саме у ньому фактично визнається проведення інформаційних операцій Росією на території України. Якщо звернути увагу на статті 20-21 даного нормативного акту, то побачимо: «Статья 20. Стратегической целью обеспечения информационной безопасности в области обороны страны является защита жизненно важных интересов личности, общества и государства от внутренних и внешних угроз, связанных $c$ применением информационных технологий в военно-политических целях, противоречащих международному праву, в том числе в цчелях осуществления враждебных действий и актов агрессии, направленных на подрыв суверенитета, нарушение территориальной целостности государств и представляющих угрозу международному миру, безопасности и стратегической стабильности». А статтею 21-ю цієї ж Доктрини визначається механізм удосконалення систем інформаційної безпеки збройних сил РФ та відповідно створення нових підрозділів інформаційного протиборства.

За інформацією Головного управління розвідки МОУ, з метою підвищення ефективності ведення інформаційної війни проти України керівництвом ГШ ЗС РФ у складі Центру територіальних військ Південного військового округу РФ створено Управління інформаційного протиборства [12]. Українська розвідка оприлюднила організаційно-штатну структуру даного підрозділу (Див. табл. 2).

Під час проведення інформаційних операцій Кремль використовує тактику дій, яка відповідає вимогам системи, яка діє в цей час. Деякі теми є основними темами у російських ЗМІ. Наприклад, постійно протиставляються традиційні цінності РФ до демократичних цінностей Свропи. Оскільки інформаційні операції агресора є сегментованими, то дискусії варіюються в залежності від територіального запиту. Робота з внутрішньою аудиторією проводиться не менша, ніж із зовнішньою. На тактичному й оперативному рівнях місцеві командири проводять власні інформаційні кампанії. Найчастіше можна зустріти короткі, часто суперечливі повідомлення, розраховані на споживання у ситуаціях підвищеної напруги або максимального розслаблення.

Ми вже зіштовхувалися із повідомленнями, коли на стільникові телефони громадян, які тимчасово або постійно проживають на Сході України, надходили смс-повідомлення із погрозами, наклепами або закликами до повалення влади. Такі повідомлення можуть мати надзвичайно негативний психологічний вплив, особливо на ту категорію населення, яка не має безпосереднього контакту із мирним, звичним середовищем. Тому проблема заповнення інформаційного вакууму на території про- 


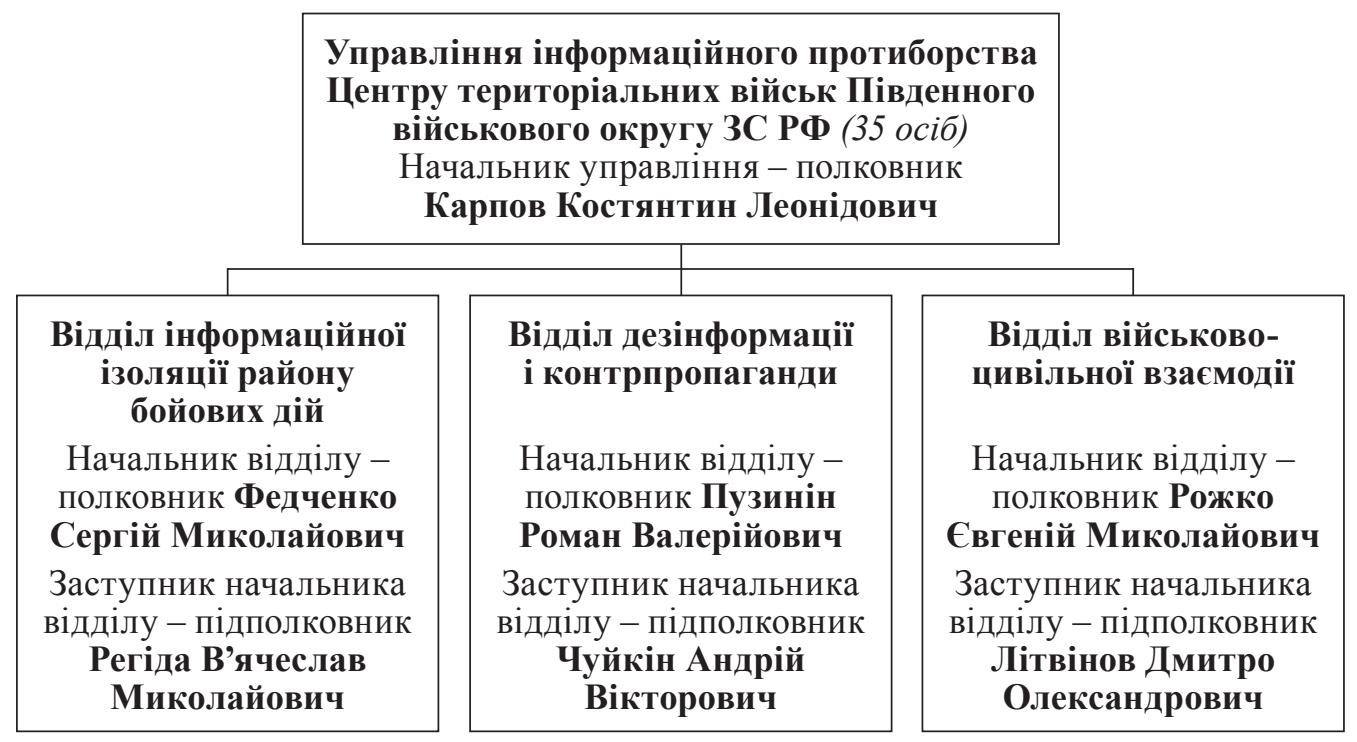

ведення ООС контентом із офіційних джерел чи якісної періодики потребує особливої уваги.

Тому для того, щоб розуміти, як протистояти інформаційним операціям з боку агресора чи активно протидіяти, потрібно вивчати аудиторію. У своїх працях засновники поняття «стратегічні комунікації» виділяють чотири способи роботи із аудиторією [13]:

- точна ідентифікація оптимальної цільової аудиторії;

- вимірювання «сугестивності» цієї аудиторії;

- визначення найкращих процесів впливу на аудиторію;

- виготовлення та поширення тригерів, які зможуть ефективно та змінювати поведінку аудиторії, основне, що це можна буде виміряти.

Сьогодні ж надзвичайно активно проводиться робота із протидії агресивним діям Кремля у публічному середовищі. За останні роки Європа, розуміючи небезпеку для власного інформаційного середовища та як наслідок територій, створила декілька робочих груп із вивчення досвіду інформаційних операції РФ проти України та Заходу, збільшила фінансування контрзаходів та заходів із попередження можливих загроз, запровадили безліч медійних освітніх проектів тощо.

Та невирішеними залишаються ще багато питань. По-перше, запровадження механізму виявлення на ранніх стадіях інформаційних операцій РФ та оперативна відповідь на них; по-друге, створення сильних стратегічних наративів, які б формували національну стійкість до ворожих інформаційних впливів; по-третє, залучення до комунікації фахівців із суміжних гуманітарних та технічних галузей; четверте, переведення роботи жорстких ієрархічних вертикалей на функціонування в системі партнерства.

Таким чином, фізичний театр воєнних дій в Україні є продовження агресивної політики Кремля в інформаційному просторі. Стратегічні документи РФ деклару- 
ють позицію наступу, а не оборони. Отож, інформаційна безпека нашої держави, а також всього західного світу, сьогодні залежить не лише від своєчасної відповіді на інформаційні операції Росії чи відкрите вторгнення, а й від вміння створити та реалізувати власний стратегічний сценарій інформаційних заходів для захисту нашої держави.

\section{REFERENCES}

1. Гусаров В. Сили інформаційних операцій Росії: яким має бути відповідь України? [Електронний ресурс] / В'ячеслав Гусаров // Інформаційно-аналітичний центр Національної Безпеки України. 2014. Режим доступу до ресурсу: http://mediarnbo. org/2014/10/07/sili-informatsiynih-operatsiy-rosiyi-yak/.

2. Осьодло В. І. Інформаційно-комунікативні технології в гуманітарній сфері Збройних Сил України: досвід, проблеми, перспективи: Підручник / В. І. Осьодло, В. В. Стасюк, В. П. Шевчук та ін.; За заг. ред. В. Г. Радецького. К.: НАОУ, 2007. $492 \mathrm{c}$.

3. Інформаційний вплив: теорія і практика прогнозування : монографія / за ред. П. Д. Фролова; Національна акад. пед. наук України, Ін-т соц. та політ. психології. К. : Міленіум, 2011. 304 с.

4. Сугестивні технології маніпулятивного впливу : навч. посіб. / [В.М.Петрик, М.М.Присяжнюк, Л.Ф.Компанцева, Є.Д.Скулиш, О.Д.Бойко, В.В.Остроухов]; за заг. ред. Є.Д.Скулиша. 2-ге вид. К.: ЗАТ «ВІПОЛ», 2011. 248 с.

5. Pomerantsev P. Can Ukraine Win Its Information War With Russia? [Electronic resource] / Peter Pomerantsev // The Atlantic. - Mode of access: http://www. theatlantic.com/ international/archive/2014/0 6/can-ukraine-win-its-information-war-withrussia/372564/

6. Почепцов Г. Інформаційні війни: базові параметри [Електронний ресурс] / Г. Почепцов // MediaSapiens. 2012. Режим доступу до ресурсу: https://ms.detector.media/ ethics/manipulation/informatsiyni_viyni_bazovi_parametri/.

7. Information Operations. Air Force Doctrine Document 2-5. 11 January 2005. 54 p.

8. Феклістов А. Сучасні погляди на місце інформаційних операцій в системах інформаційної боротьби / А. Феклістов. // Проблеми оперативного мистецтва та тактики. 2010. С. 25-27.

9. Мінаков О. Гібридна війна Росії. Трансформація маніпуляцій у соцмережах [Електронний ресурс] / Олексій Мінаков // Радіо Свобода. 2017. Режим доступу до pecypcy: https://www.radiosvoboda.org/a/28498431.html.

10. Почепцов Г. Смислові та інформаційні війни: пошук відмінностей [Електронний pecypc] / Г. Почепцов // MediaSapiens. 2013. Режим доступу до ресурсу: https:// $\mathrm{ms}$.detector.media/ethics/manipulation/smislovi_ta_informatsiyni_viyni_poshuk_ vidminnostey/.

11. Війна і пропаганда. Як працюють війська інформаційних операцій Росії? [Електронний ресурс] // Радіо Свобода. 2017. Режим доступу до ресурсу: https://www. radiosvoboda.org/a/28351969.html.

12. Особливості діяльності Управління інформаційного протиборства Центру територіальних військ Південного військового округу ЗС РФ [Електронний ресурс] // ГУР МОУ - Режим доступу до ресурсу: http://gur.mil.gov.ua/content/osoblyvosti- 
diialnosti-upravlinnia-informatsiinoho-protyborstva-tsentru-terytorialnykh-viiskpivdennoho-viiskovoho-okruhu-zs-rf.html.

13. Rowland L., Tatham S. Strategic communication \& influence operations: do we really get it? Shrivenham, 2008.

\title{
THE WAR OF UKRAINE: FROM INFORMATION OPERATIONS TO DIRECT INFRINGEMENT
}

\author{
Anhelika Dilai \\ Military Institute of Taras Shevchenko National University of Kyiv, \\ Lomonosova street, 81, 03189, Kyiv, Ukraine \\ e-mail: likadilay@ukr.net \\ https://orcid.org/0000-0002-8255-4941
}

In this article the information operations are analyzed as a preparatory stage for the capture of the borders of foreign states, the strategic documents that regulate the activities of the information combat divisions are studied. The author drew attention to the concept of influence as the basis for the implementation of information operations. Also, the author attempted to isolate the problem issues of counteracting Ukraine with information operations on the part of the Kremlin.

The similarity of the concepts of information war, informational confrontation, information struggle, information operations are analyzed. The definition of the informational and psychological impact as different concepts, which formed the basis of a single definition of information and psychological impact as the basis of information operations, is given.

The article traces the transformation of the term «information operation» to the term «influence operations», which fully reflect the current policy of waging war. The author also focuses on the characteristics of the audience of consumption and the need for its study to effectively achieve their communication goals.

As a result, we see that the modern world is full of challenges to the information security of countries. Therefore, a strong system of protecting the information space, as well as the ability to predict possible threats today are a necessary condition for the preservation of territories, as well as their own values.

Key words: information operations, influence, mass-media. 